\title{
DESAIN PROTOTIPE MOTOR INDUKSI 3 FASA
}

\author{
Jumanto, Hasyim Asy'ari, Agus Supardi \\ Jurusan Teknik Elektro Fakultas Teknik Universitas Muhammadiyah Surakarta \\ J1. A. Yani Tromol Pos 1 Pabelan Kartasura 57102 Telp 0271717417 \\ Email: jumnyunk@gmail.com
}

\begin{abstract}
ABSTRAKSI
Hampir di setiap rumah tangga dan industri menggunakan mesin listrik untuk mempermudah pekerjaan. Jenis mesin listrik yang umum digunakan adalah motor induksi. Hal ini disebabkan karena jenis motor induksi mempunyai kelebihan-kelebihan dibandingkan dengan jenis motor lainnya, antara lain karena konstruksinya sederhana dan harganya yang relative murah serta lebih ringan. Penelitian ini bertujuan membuat prototipe motor induksi 3 fasa dan mengetahui karakteristik hasil output RPM dari motor induksi tersebut.

Desain prototipe motor induksi 3 fasa pada bagian statornya memanfaatkan bahan-bahan seperti koker sebanyak 6 buah dengan ukuran $6 \mathrm{~cm} \times 4,2 \mathrm{~cm}$, inti besi atau current berbentuk E sebanyak 168 buah dengan ukuran 6,6 cm $x$ 4,4 cm dan current berbentuk I sebanyak 174 buah dengan ukuran 6,6 cm, untuk kumparannya menggunakan kawat email berdiameter 0,3 mm dengan jumlah 2200 lilitan. Pada bagian rotornya memanfaatkan kaleng bekas diberi belitan mengelilingi sisi-sisi kaleng. Pengujian motor induksi 3 fasa pada saat kaleng diberi belitan dan kaleng tanpa belitan. Pengamatan yang dilakukan adalah pengambilan data terkait tegangan input, arus dan RPM.

Hasil penelitian menunjukkan bahwa pada saat tegangan input 50 volt rotor belum dapat berputar. Namun pada saat tegangan input 75 volt sampai 200 volt rotor dapat berputar secara perlahan sesuai tegangan yang dimasukkan, kecepatan putar rotor tersebut mencapai 290,3 RPM. Sedangkan pada saat rotor tanpa diberi belitan penelitian menunjukkan bahwa pada saat tegangan input 50 volt sampai 125 volt rotor belum dapat berputar, kemudian pada saat tegangan input 150 volt sampai 200 volt rotor dapat berputar namun sangat pelan hanya mencapai kecepatan putar maksimal 64,4 RPM. Hal ini disebabkan pada saat rotor tanpa diberi belitan, karena rotor tidak dapat menangkap medan magnet yang dikeluarkan oleh stator sehingga kumparan rotor tidak dapat mengalami gaya Lorentz yang menimbulkan torsi yang cenderung menggerakkan rotor sesuai arah pergerakan medan induksi stator.
\end{abstract}

Kata kunci: prototipe motor induksi, motor induksi 3 fasa, RPM, motor listrik, rotor.

\section{PENDAHULUAN}

Hampir disetiap rumah tangga dan industri terdapat mesin listrik yang sering dikenal sebagai motor induksi, pada rumah tangga lebih dari $75 \%$ terlah menggunakan atau memanfaatkan pompa air, mesin pompa ini termasuk motor induksi, contoh peralatan lain yang sudah banyak dimanfaatkan oleh masyarakat adalah, Fan, hair dryer, sedangkan untuk kegiatan industri motor induksi banyak sekali ditemukan untuk menggerakkan peralatan produksi, misalkan pada industry terxtile motor industry digunakan untuk peralatan di bagian spinning, proses pengolahan limbah.

Mempelajari perilaku dari suatu motor yang akan digunakan untuk menggerakkan mesin atau peralatan industri, maka salah satu masalah yang harus diperhitungkan adalah menentukan apakah karakteristik torsi kecepatan dari motor tersebut sesuai dengan persyaratan yang dibutuhkan oleh beban yang digerakkan.

Terlepas dari pertimbangan karakteristik listrik mesin penggerak ini, maka terdapat tiga parameter mekanisme yang sangat dipertimbangkan oleh pengguna, yaitu; kecepatan putaran, torsi yang dihasilkan dan daya output mekanismenya. Besaran-besaran ini relative sulit ditentukan, sehingga terlebih dahulu perlu peninjauan kembali sejumlah metode pengukuran yang umum digunakan untuk mengetahui dan mempelajari besaranbesaran tersebut.

Jenis motor listrik yang umum digunakan sebagai motor penggerak mesin atau peralatan dalam industri, maka motor induksi merupakan jenis motor listrik yang sangat luas penggunaanya. Hal ini disebabkan karena jenis motor ini mempunyai kelebihan-kelebihan dibandingkan dengan jenis motor lainnya, antara lain karena konstruksinya sederhana, lebih reliable dan yang lebih penting lagi 
adalah harganya yang relative murah serta lebih ringan.

Transformator adalah suatu alat listrik yang dapat memindahkan dan mengubah energi listrik dari satu atau lebih rangkaian listrik ke rangkaian listrik yang lain, melalui suatu gandengan magnet dan berdasarkan prinsip induksi-elektromagnet. Transformator digunakan secara luas, baik dalam bidang tenaga listrik maupun elektronika.

\section{METODE PENELITIAN}

2.1 Bahan dan Peralatan yang digunakan

Proses pembuatan prototype motor induksi ini terdiri dari beberapa komponen, yaitu.

a. Current berbentuk E sebanyak 168 buah dengan spesifikasi $6,6 \mathrm{~cm} \times 4,4 \mathrm{~cm}$ dan current berbentuk I sebanyak 174 buah dengan spesifikasi $6,6 \mathrm{~cm} \times 1 \mathrm{~cm}$.

b. Koker sebanyak 6 buah dengan spesifikasi $6 \mathrm{~cm} \times 4,2 \mathrm{~cm}$.

c. Kawat email 0,3 mm dengan 2200 lilitan 1 buah kumpran.

d. Kertas minyak, solasi dan baut besi 12 buah.

e. Kawat email 0,3 mm dengan 2200 lilitan 1 buah kumpran.

f. Kaleng untuk pengganti rotornya dan as penggerak.

g. MCB 16 Ampere.

h. Multimeter digital untuk mengukur tegangan dan arus.

i. Tachometer untuk mengukur kecepatan putaran motor.

j. Autotrafo voltage regulator 3 fasa untuk mengatur tegangan.

k. Tang dan obeng.

2.2 Tahap Pengolahan Data

Analisis pengolahan data prototipe motor induksi 3 fasa, langkah-langkah yang akan dilakukan sebagai berikut :

a. Merancang lilitan kumparan pada koker dan merancang prototipe.

b. Merangkai rangka prototipe motor induksi.

c. Melilit dan memasang lilitan kumparan pada koker.

d. Merangkai prototipe motor induksi. e. Pengujian prototype motor induksi dengan menyambungkannya ke sumber listrik.

f. Pengukuran tegangan input, arus dan hasil output RPM dan menganalisis hasil pengukuran.

g. Membuat kesimpulan.

2.3 Diagram Alir Penelitian

Penelitian diawali dengan merancang prototipe motor induksi, merakit koker, kawat email untuk dijadikan sebuah prototipe motor induksi 3 fasa. Setelah didapatkan prototipe tersebut dilanjutkan pengujian. Secara detail diagram alir penelitian ditunjukkan pada gambar 1.

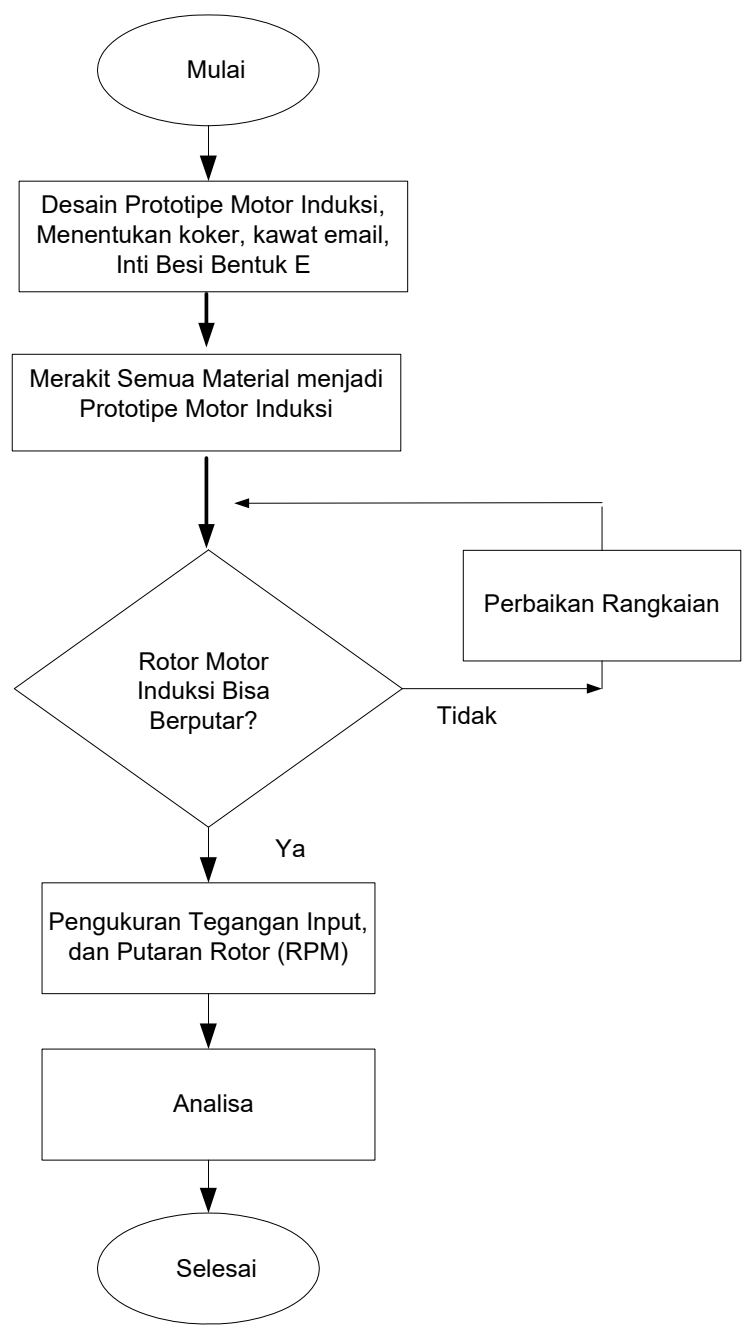

Gambar 1. Diagram Alir Penelitian 


\section{HASIL DAN ANALISA}

Penelitian yang dilakukan adalah membuat prototipe motor induksi 3 fasa yang memanfaatkan bahan-bahan trafo seperti koker sebagai rumah kumparan, current sebagai inti besi untuk menghasilkan magnet karena adanya kumparan yang dialiri listrik, kawat email dan memanfaatkan kaleng bekas sebagai rotornya. Data penelitian berikut berdasarkan pada hasil pengujian prototipe motor induksi menggunakan sumber listrik PLN 3 fasa yang diatur tegangannya menggunakan autotrafo voltage regulator 3 fasa, kemudian pengukuran meliputi tegangan input, arus dan kecepatan putaran rotor motor induksi (RPM). dan 2

Hasil pengujian ditunjukkan pada tabel 1

Tabel 1. Pengujian pada saat kaleng sebagai rotor diberi belitan yang membentuk rangkaian tertutup

\begin{tabular}{cccc}
\hline No & $\begin{array}{c}\text { Tegangan } \\
(\mathrm{V})\end{array}$ & $\begin{array}{c}\text { Arus } \\
\text { (Ampere) }\end{array}$ & RPM \\
\hline 1 & 50 & 0,38 & - \\
2 & 75 & 0,57 & 58,4 \\
3 & 100 & 0,8 & 70,1 \\
4 & 125 & 0,95 & 130 \\
5 & 150 & 1,15 & 202,9 \\
6 & 175 & 1,36 & 240,1 \\
7 & 200 & 1,58 & 290,3 \\
\hline
\end{tabular}

Tabel 2. Pengukuran tegangan input, arus dan RPM

\begin{tabular}{cccc}
\hline No & $\begin{array}{c}\text { Tegangan } \\
(\mathrm{V})\end{array}$ & $\begin{array}{c}\text { Arus } \\
\text { (Ampere) }\end{array}$ & RPM \\
\hline 1 & 50 & 0,38 & - \\
2 & 75 & 0,57 & - \\
3 & 100 & 0,8 & - \\
4 & 125 & 0,95 & - \\
5 & 150 & 1,15 & 23,4 \\
6 & 175 & 1,36 & 38,9 \\
7 & 200 & 1,58 & 64,4 \\
\hline
\end{tabular}

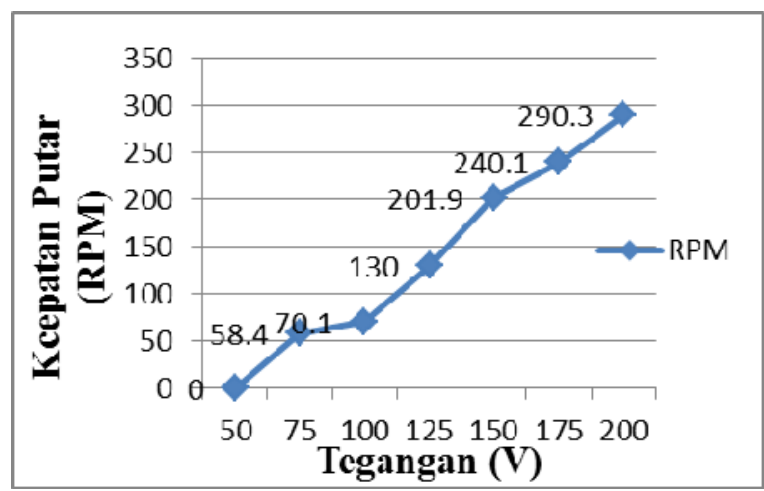

Gambar 2. Hubungan Tegangan Input terhadap Kecepatan Putar Rotor yang Ditambah Rangkaian Terturup

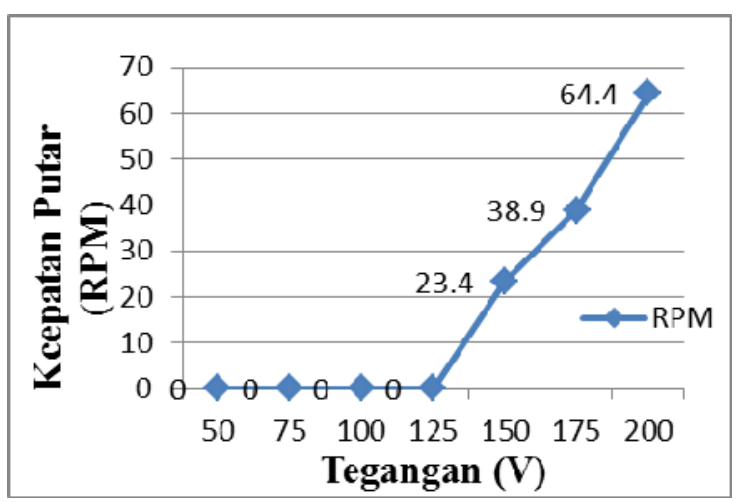

Gambar 3. Hubungan Tegangan Input terhadap Kecepatan Putar Rotor tampa Penambahan Rangkaian Terturup

Pada gambar 2 menunjukkan bahwa pada posisi tegangan 50 volt belum menunjukan indikasi rotor kaleng berputar atau tidak berputar, ini dikarenakan medan magnet yang dihasilkan belum mampu menggerakkan rotor tersebut. Posisi tegangan dinaikan hingga 75 volt dan arus juga naik hingga 0,57 A maka rotor kaleng berputar pelan dengan kecepatan putar 58,4 Rpm. Tegangan kemudian kembali dinaikkan hingga 100 volt, arus kembali naik hingga 0,80 A secara otomatis mempengaruhi kecepatan rotor kaleng hingga 70,1 Rpm. Selisih putaran rotornya dari tegangan sebelumnya hanya 11,7 Rpm. Pada tegangan 125 volt dengan arus 0,95 A putaran rotor kaleng $130 \mathrm{Rpm}$. Selisih dari tegangan sebelumnya lumayan tinggi hingga 59,9 Rpm. Memasuki tegangan 150 volt dan arus 1,15 A kemudian puturan rotornya 202,9 Rpm. Selisihnya menurun sedikit dari sebelumnya menjadi 72,9 Rpm. Tegangan lebih besar lagi 
diposisi 175 volt dan arus 1,36 A berlanjut puturan ikut naik sebesar 240,1 Rpm. Putarannya terlihat naik tetapi selisih dari sebelumnya menjadi $37,2 \mathrm{Rpm}$ saja. Pada tegangan 200 volt arus 1,58 A putaran rotor kembali naik hingga 290,3 Rpm. Ketika ditegangan 200 volt kembali naik tetapi selisihnya hanya 50,2 Rpm.

Berdasarkan gambar 2 sesuai percobaan, tegangan yang semakin tinggi mempengaruhi kecepatan putar rotornya. Tetapi dipercobaan ini pada saat tegangan dinaikkan lebih tinggi lagi kumparan menjadi panas dan jika terlalu lama pemakaian atau terlalu lama dalam menyala juga mempengaruhi tahanan kumparan tersebut. Pada saat kumparan mulai panas dikarenakan kurang banyaknya jumlah lilitan tersebut. Kemudian rotor tidak berputar dengan cepat sesuai perhitungan dikarenakan rotornya menggunakan kaleng, meskipun sudah dimodifikasi dengan adanya belitan dikeliling kaleng tersebut.

Pada gambar 3 menunjukkan bahwa pada posisi tegangan 50 volt sampai 125 volt kaleng tidak dapat berputar, karena sisi-sisi kaleng yang sama sehingga tarikkan magnet dari stator tidak mampu memutarkan kaleng. Kaleng terbsebut terkesan bingung akan memutar ke arah kanan atau ke arah kiri. Hanya bergerak ke kanan dan ke kiri terus menerus. Pada tegangan 150 volt kaleng dapat berputar sangat pelan dan awal ketika hendak berputar sangat terasa berat dan RPM hanya 23,4 RPM. Tegangan di posisi 175 volt kecepatan putar bertambah tetapi masih sangat pelan hanya 38,9 RPM. Pada Tegangan 200 volt kecepatan putar mencapai 64,4 RPM. Hali ini disebabkan sisi-sisi kaleng sama rata sehingga tarikkan magnet sama kuat dan putaran tidak maksimal.

Kaleng dengan modifikasi dapat berputar maksimal karena adanya belitan yang melingkari kaleng tersebut. Kaleng dapat menyimpan induksi dari stator yang mengahasilkan induksi. Kaleng dengan adanya belitan yang melingkar bisa berfungsi juga untuk memutus dan menyambungkan tarikan magnet sehingga kaleng berputar sesuai dengan tarikkan magnet.
Sedangkan kaleng tanpa modifikasi sebenarnya dapat berputar tetapi sangat berat, hal ini disebabkan sisi-sisi kaleng tersebut sama rata sehingga tarikkan magnet juga sama-sama kuat, sehingga kaleng hanya berputar ditegangan tinggi dan tidak berputar ditegangan rendah. Kaleng tersebut hanya berputar ke kanan dan ke kiri seolah bingung kaleng akan berputar ke arah kanan atau kiri.

\subsection{Perbandingan Kecepatan Putar Motor} Dengan Hitung Rumus.

a. Kecepatan medan putar (Ns).

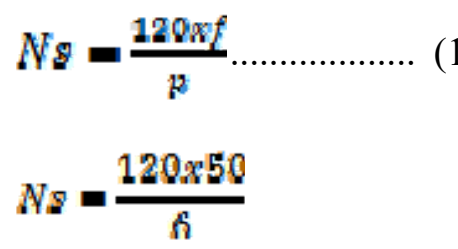

\section{$N s=1000 R P M$}

b. Perbedaan kecepatan antara $\mathrm{Nr}$ (kecepatan medan putar) dan Ns (kecepatan medan putar stator) atau yang sering disebut Slip (S) ketika tegangan $200 \mathrm{~V}$.

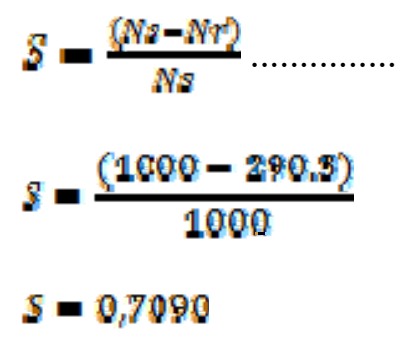

Persamaan slip dapat pula dalam bentuk persen:

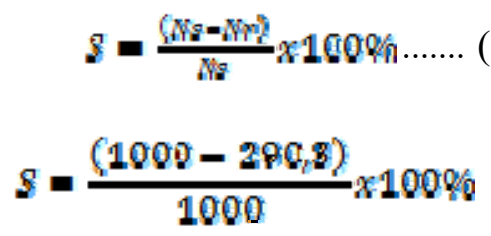

$\boldsymbol{s}=70,97 \%$ 
Hasil perhitungan slip dapat dilihat pada tabel 3. dari tegangan 50 volt sampai 200 volt.

Tabel 3. Slip Motor Induksi Pada Saat Rotor diberi Rangkaian Tertutup

\begin{tabular}{ccc}
\hline No & $\begin{array}{c}\text { Tegangan Input } \\
(\mathrm{V})\end{array}$ & Slip (\%) \\
\hline 1 & 50 & 100 \\
2 & 75 & 94,16 \\
3 & 100 & 92,9 \\
4 & 125 & 87 \\
5 & 150 & 79,7 \\
6 & 175 & 75,9 \\
7 & 200 & 70,9 \\
\hline
\end{tabular}

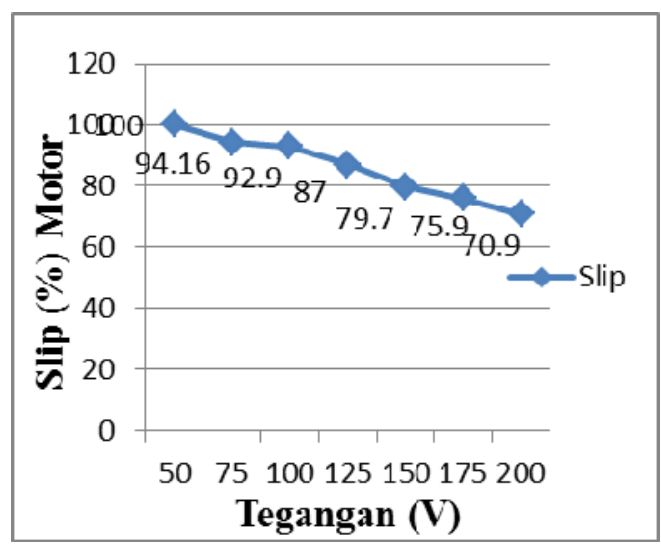

Gambar 4. Hubungan Antara Tegangan Input dan Slip

Berdasarkan perhitungan slip antar tegangan, tegangan 50 volt paling besar ini dikarenakan kaleng tidak berputar sehingga slip $100 \%$. Pada saat tegangan 75 volt slip masih besar hingga 94,16 \% dikarenakan kecepatan putar hanya 32,4 RPM. Tegangan 100 volt slip menurun tetapi masih besar hingga 92,9 \%. Tegangan dinaikkan kembali hingga 125 volt, slip juga masih terlihat besar $87 \%$. Tegangan 150 volt slip motor kembali menurun hingga 79,7 \%. Memasuki tegangan 175 volt menimbulkan slip 75,9\%. Terakhir ditegangan 200 volt menimbulkan slip 70,9\%, menurun dan paling kecil dari tegangan yang lainnya tetapi slip ini masih terlihat besar. Hal ini disebabkan kecepatan putar kaleng tidak sampai setengah dari kecepatan medan putar yang sudah dihitung mencapai 1000 RPM.
Slip terjadi kareana adanya perbedaan antara kecepatan medan putar (synchronous speed) dan kecepatan rotor (rotor speed).

\section{KESIMPULAN}

Berdasarkan pengujian dan analisis desain prototipe motor induksi 3 fasa dengan pemanfaatkan bahan-bahan trafo sebagai stator dan kaleng sebagai rotor dapat ditarik kesimpulan bahwa :

1. Hasil pengujian kaleng modifikasi menunjukkan bahwa pada saat tegangan 50 volt rotor belum dapat berputar. Tegangan dinaikkan ke 75 volt secara berturut-turut hingga tegangan 200 volt dapat mencapai keceptan putar maksimal 290,3 RPM.

2. Sedangkan pengujian kaleng tanpa modifikasi atau tanpa belitan, pada saat tegangan 50 volt secara berturut-turut sampai teganga 125 volt rotor belum dapat berputar. Pada saat tegangan dinaikkan hingga 150 volt sampai 200 volt dapat mencapai kecepatan putar maksimal hanya 64,4 RPM.

3. Berdasarkan analisis, ketika kaleng diberi belitan dapat menginduksi tegangan dari stator tersebut, namun pada saat kaleng tanpa belitan atau tanpa modifikasi tidak dapat menginduksi secara maksimal, karena sisi-sisi kaleng sama rata sehingga tarikan magnet sama kuat membuat kaleng berputar antara ke kanan atau ke kiri.

\section{DAFTAR PUSTAKA}

Anonim. 2012. Teori Dasar Motor Induksi.http://www.teknikelektro.co $\mathrm{m} /$ teori-dasar/teori-dasar-motorinduksi/. Diakses pada tanggal 15 januari 2014.

Anonim. 2013. Teori Motor Induksi. http://www.slideshare.net/NemoGala $\mathrm{u} /$ teori-motorinduksi. Diakses pada tanggal 15 januari 2014.

Efendy, Machmud. 2009. Rancang Bangun Motor Induksi Sebagai Generator (MISG) Pada Pembangkit Listrik Tenaga Mikrohidro. Universitas Muhammadiyah Malang. 
Gunawan, Hanapi. 1993. Mesin dan Rangkaian Listrik. Jakarta : Erlangga.

Sarjan, Muhammad. 2011. Perbandingan Karakteristik Motor Induksi Belitan Gelung Dengan Belitan Spiral. Universitas Tadulako.
Sumanto. 1993. Motor Listrik Arus Bolakbalik. Yogyakarta : Andi Offset.

Yunus, Yadi. Suyamto. 2008. Rancang Bangun Alat Pengatur Kecepatan Motor Induksi Dengan Cara Mengatur Frekuensi. Sekolah Tinggi Teknologi Nuklir-BATAN. 